\title{
Playing and Creativity as Pedagogical Strategies to Face the New Challenges of Education in Colombia
}

\author{
Omar Cabrales Salazar, Rafael Alfonso Martínez Herrera, Jorge Antonio Bermúdez Mejía
}

School of Education and Humanities, Universidad Militar Nueva Granada, Bogotá, Colombia

\section{Email address:}

omar.cabrales@unimilitar.edu.co (O.C. Salazar), teacher28rafael@gmail.com (R. A. M. Herrera), jorge.bermudez@unimilitar.edu.co(J. A. B. Mejía)

\section{To cite this article:}

Omar Cabrales Salazar, Rafael Alfonso Martínez Herrera, Jorge Antonio Bermúdez Mejía. Playing and Creativity as Pedagogical Strategies to Face the New Challenges of Education in Colombia. Science Journal of Education. Vol. 5, No. 6, 2017, pp. $244-251$.

doi: $10.11648 /$ j.sjedu. 20170506.13

Received: October 25, 2017; Accepted: November 23, 2017; Published: December 15, 2017

\begin{abstract}
This paper will further discuss the need to incorporate creativity in university teaching practices based on playing as a didactic strategy. The above, by considering the challenges that when facing the post-conflict, higher education in Colombia is dealing with as mediated by the new technologies and the advances that the stimulation of creativity implies in the students of today. In this respect, this paper first details the impact the armed conflict has had in Colombian education and, later, elaborates on the relevance of bringing different teaching strategies associated with playing to help develop creativity and improve the teaching practices in higher education in Colombia.
\end{abstract}

Keywords: Playing, Creativity, Post-Conflict, Pedagogical Strategies

\section{Introduction}

The signing of a peace agreement with the FARC (Revolutionary Armed Forces of Colombia), is already an unobjectionable fact. They have surrendered their weapons and begun a process of incorporation into civilian life, something unthinkable for the Colombian society some years ago. Aditionally, young people who reach higher education, are showing other common imaginary and conceptions of the world which are structured in the everyday use of technology in both their daily and academic lives. Meanwhile, education in Colombia remains anchored in old and ossified conceptions of teaching, assuming that the minds of the youth of today -already forged into the world of technology and interconnection- are equal to those old generations, when Christmas would take long to come and the year 2000 seemed an apocalyptic date that would never be reached. The toiled boring indeed concept of 'life plan' which is focused on the final stages of life, on one's established goals and the way forward for the future is being reevaluated because existence has become an unfinished state. Besides, this state is one in which the inconveniences and variations of fate are faced or eluded with the fragile tools that immediacy allows.

Accordingly, first this article briefly diagnoses the changes higher education has suffered in connection with the use of technology in the classrooms. Then it highlights the importance to look for innovative ways to bring students and knowledge together and, finally, it argues for the need to implement new teaching strategies supported in the condition of mutability of the human being lying on creativity and playing. The latter, in order to promote the integral development of the new type of students and, later, of the former fighters who will join civil life in the new postconflict scenario in Colombia. With this in mind, universities will have to innovate and start designing pedagogical strategies to teach the people whose lives are being mediated by the use of technology and some whose lives have revolved around the jungle and have experienced the circumstances of war where weapons have been their tools.

\section{A New University}

The idea of a specific domain and a final state faces new challenges, not only for the articulation of new concepts of human development, but also for the way the world is developing (...). The longer the duration of life and the more there are global and technological changes, the more a new goal is required, the new goal of human potential. This one is 
a set of properties or skills and competences that make the individual an efficient navigator in a changing world. [5]

Many psychological theories have the merit they deserve; the model of cognitive development by Piaget [28] or Erikson's model of psychosocial stages [11], for example. When laying the foundations of behavior and learning, both contributed to the formation of a theoretical framework that has allowed an approach, with scientific tools, to the training of people in educational settings. "However, the goals and contexts of human development are more complex, dynamic and variable than these traditional views based on specific definitions of domains, or suggested by the final states." [5]. It is therefore necessary to understand the final states as those stadiums or goals to which people used to look forward to as moving in the path of destiny to adulthood. They need to be understood as those purposes that would imply the fact of overcoming stages and leaving them behind to finally reach the stability of a successful, mature life, when almost everything was supposedly resolved.

While in the past the world presented a set of conditions in which adulthood was the same as maturity, where becoming an adult was a relatively fixed target and where being, (i.e., achieving and retaining a relatively stable condition) was a possibility, in the modern world, adulthood is not the final stage of life but remains a constant state of change or transition to subsequent stages [5].

Consequently, the theories of the final states are giving way to a new conception of life in which, in the context of globalization and competitiveness, the stability and course of the existence of people are not seen as it was thirty years ago. In fact, today "it is debatable whether the modern world is focused on living conditions where the main aspect is not the definition of a final particular stage, but the shaping of a behavioral system that globally promotes continuous adaptation and mastering of new circumstances of life." [5]

It is a fact that university education in Colombia is relegating the necessary dynamics that the post-conflict is demanding in a country that seems lethargic in its bureaucracy and outdated curricula. A society where Academia does not respond with creativity, promptness and certainty to the constant changes even though it is aimed at working with people whose essential condition is to have the possibility to transform; to reach higher levels of knowledge and civility.

Education has been one of the most affected areas by violence in Colombia. The normalization of violent behavior, corruption, institutional deficit and State absence [1,22], and the lack of job opportunities in our country, among other factors, have allowed the emergence and consolidation of multiple illegal actors, leading to the strengthening of violence and unlawful armed groups.

In this context, higher education is responsible for bringing former fighters back to civil life and thus becoming a factor for pacification and economic growth. More importantly, these factors will compel the universities to respond with educational processes since this change includes not only having these people back in the classrooms but also modifying their selective structures. By considering these modifications, the university will be more open to society and its nearest areas of influence: family, industry, graduates, social groups, etc., to finally become a generator of development and stabilizer of new peace circumstances.

On the other hand, it is necessary to consider educating the youth of today more in touch with each other through the advances in technology. Generation $Z$, the Millennium Generation or that of the digital natives [30] understand what humanity entails since, by being unlearned from the past, they are constantly connected; they are pragmatic, stubborn, independent, ambitious and focused on the immediate future. These generations, made of those born between the mid-90s and the early twenty-first century, are determined to build a different world than that of their elders, their minds seem to be set away from existing social codes and mediated by technology. According to a newspaper article by El Tiempo [10], these young people "[...] read very little, do not practice sports and do not lose sleep for educating themselves and find a job to have a living. Instead, as in any other generation, this one of 'mutants' (as some researchers refer to, by their combining with the digital world) is ready to absorb new technologies."

Change is undoubtedly a human attribute to be reflected in university as it being one of the spaces of preparation that receives new young people term after term. This context cannot leave behind this exchange that society is crying out for. In fact, more than any other institution, this one is forced to change its governing models, its obsolete and outdated teaching models and practices because, as a managing body of new knowledge, it must not only adapt to change but also promote it through innovation and creativity, which are its missionary purposes. In addition, the university receives term after term the raw material of youth, which comes with new ideas and ways of learning, with new demands for a changing world. Similarly, it cannot pursue an exclusive status as the irreplaceable handler of knowledge, knowing that there are other institutions, like Apple and Google, that also produce, reproduce and disseminate knowledge sometimes more expeditiously.

\section{New Ways of Teaching}

The effects of globalization and the preponderance of mass media on the ways of living of our society should define new ways of teaching and learning. The explosive development of our sources of socialization, which is frequently in rivalry with the school experience (Internet, mass media, youth peer groups) $[12,18]$, demand the creation of ways of teaching according to the underlying lifestyles and should then be included in the new categories implied in an interconnected world. This, by having with sufficient opportunities to obtain information and share knowledge.

In this regard, higher education can no longer confine people for hours to listen to a teacher talking about subjects that are available online; a teacher cannot go and read over 40 slides, which at best, has also downloaded from Internet. 
The considerations of what a class was before new technologies came into play must evolve towards more participatory, more playful, more fun and more creative stages. Bruner's book: Beyond the Information Given [7] provides a convincing case for focusing on cognitive processes including problem solving, exploration, and playing. This leads to help us define a new basis for developing the curriculum of our institutions. A life that is lived in a world in front of a monitor or a smartphone, in other words, 'connected', transcends the senses and builds new ways of seeing reality and unreality. It constructs new ways to feel, to establish relationships, to have fun and find new ways of thinking. Young people feel more connected to each other through the Internet/internet sites they frequently visit and video games they often play than in their face-toface classrooms.

In this regards, an inclusive type of education must be adopted to successfully attend the need for new ways of teaching, considering the possibility of having a more varied population of students at university. Then, thinking globally about college is realizing that students have access, in just seconds, to lots of information through texts, images, and videos on their smartphones or tablets; access to remote places where they would like to be, or to hundreds of people they would like to talk to and meet via Skype or WhatsApp. A class in which there is a professor who speaks for 60 minutes can lead to the students' drop out because "uncertainty about the future employment of students, loss of ideological and religious certainties, the crisis of legitimacy of the political and social systems, among others, make the school appear as too rigid and stuck in the past, in the eyes of many students and their families" $[12,18]$.

This need for inclusive education aims at incorporated methodological and curricular changes to satisfy the needs of students with disabilities -former fighters and their families, for example- aiming at benefiting the community. In this respect, inclusion can be considered as a stimulus that can promote the development towards a more diverse learning environment [2]. Nevertheless, the university must first prioritize the principles of equity and inclusion, by offering unbiased education for all, without regards to their personal, religious and cultural features.

It is therefore necessary to develop creative and innovative strategies which can be achieved by emphasizing learning. In this respect, teachers who have and transmit high expectations to their students are the role models to start developing new ways of teaching. The teachers who implement a variety of teaching strategies and work together to create life-related curriculum materials under a stimulating learning environment in which creativity, joy and self-esteem become the paths par excellence.

\section{Playing and Creativity}

Playing is the universal language of childhood. In order to converse with new generations of children and youth, the teachers of today must prepare themselves and learn how this form of communication and creativity can be adapted to the classroom. [25].

The development of creativity through the intermediation of other types of thinking such as lateral thinking [9] emotional intelligence and the dynamics of playing are candidates to be some of the strategies to bring education closer to the youth of today. In terms of Johnson [24], creativity is a multifunctional construct in which interaction and the convergence of multiple spheres of thinking are shown and that is best achieved if there is inter and multidisciplinary work. From Huizinga's citing [19]: "animals have not waited for man to teach them to play," we can say that playing is an essential tool for learning, for it transcends the spheres of rationality to become materialized as a universal activity in which all creatures converge or are recognized. Children, who do not know language, can play naturally.

According to Ponce [29], systemic theories of creativity establish that the motivation for the task, relevant information in the field of knowledge, and specific and relevant creative skills are crucial for the development of intelligence that transcends the development of other cognitive spheres of the student. It is a fact that the motivation for the task, maintained by the interest of the student in an autonomous way, will trigger creativity and this, in turn, will contribute to the development of multiple intelligences.

Individuals use information in ludic or academic atmospheres and transform or extend it to new ideas through their cognitive processes, their personality traits and motivation [29]. Then, cognitive routines could be extended to unknown areas enhancing their learning processes as their cognitive processes expand, thus incorporating new and different knowledge. It is known that creative people incorporate various brain areas and different types of knowledge so as to solve problems.

Vivas \& Gallego [37] agree that an unprecedented enthusiasm about the scientific study of emotions has been observed in recent years. The unexpected sights of the brain at work, made possible by new brain imaging technologies, demystified part of the knowledge about its influence on human behavior [23]. According to Damasio [13], emotions keep curiosity, serve to communicate, and are essential in the processes of reasoning and decision-making, i.e., emotional and cognitive processes are inseparable.

Emotions play a vital role in our lives, hence the importance of knowing how they develop and how they affect personal and social adjustments and particularly how they affect learning processes that take place in educational institutions (...) In a human being, experiencing an emotion usually involves a set of cognitions, attitudes and beliefs about the world, which are used to assess a particular situation and therefore influence the way in which the situation is perceived. [36]

Certainly, there is nothing as exciting as creating, as suggesting one's own solutions emerging from ideas that, in an emotional state, a motivated brain produces from 
underlying knowledge. This domain is transformed or extended through its cognitive processes, personality traits and motivation. Therefore, according to Ponce [29], creativity can be considered an individual property, resulting from the interaction of the individual with one or more systems that in a class can become a powerful tool for learning and resilience, very useful for ex-combatants.

Creativity, in short, cannot be approached as a simple trait of human beings; it is unquestionable that aspects such as: the mind and the cognitive processes that take place in it, the personality, the motivation, the emotions and the affective world, play a unique role in this process. On the other hand, we all are creative to a greater or lesser extent and what is even more encouraging, we can all develop our creativity [14].

In groups of millennial students, the generations $\mathrm{Y}$ or $\mathrm{Z}$ or in the new post-conflict students, there are common learning problems as well as poor academic performance, as they are immersed in the same armed conflict, or in multiple stimuli that make it difficult for them to concentrate. Nuñez [23] argue that the prejudice that suggests an inability to achieve good performance in a difficult task, activates the amygdala causing nervousness, which, in turn, blocks the functioning of the prefrontal lobes, leading to poor performance. In addition, fear and conceptual gaps hinder students' concentration and do not allow the development of sufficient capacities for understanding and applying the various discourses in which they participate.

The teacher should help students discover, identify and use their skills to achieve their goals. By thinking and doing, a person is able to find strategies to develop a task in a free-ofstress environment. Along with playing, one of the factors to help intelligence develop is the enjoyment and comfort that students should experience during their learning processes. According to May [21] "Being creative needs full 'brains-on engagement' as well as the ability to use tools and equipment safely. This suggests that planning needs to incorporate the teaching of both physical and thinking skills".

It is necessary to help professors understand the importance of creativity as a capacity underlying the different ways of thinking, a skill that is required for solving problems, promoting understanding processes and meaningful learning. Beyond question, this is an essential element that the educational institutions should bear in mind. From a holistic perspective, all these concepts should develop in all individuals. In educational settings, optimizing creative skills is essential for structuring the learner since it makes the individual self-confident and motivated to undertake other types of knowledge.

The educational system requires a new comprehensive and prospective model that guides the actions of teachers and students towards very clear and dynamic purposes. The proposal of constructivism epistemology and conceptual pedagogy is the need to characterize with a futuristic approach, in which type of society students of today tomorrow's citizens-, will perform. Its pedagogical action is aimed at grooming from an early age, a human being who can perform in the knowledge society, educating him from basic levels of education to university, as an individual capable of abstraction and prospective sense, with the capacity to develop skills of thought as an ethical, independent and creative being. [26]

\section{Playing as a Learning Tool}

Beyond rational thought, whose fulfillment takes place as cognitive structures through verbal or logical-mathematical reasoning become more complex, the innocence and immaturity of childhood persist. The unawareness of death makes children innocent and playful, so animals and men children and adults- are unarmed from rational structure when playing. Maybe that is why imagination and unlikelihood are its raw materials and promote creativity by shedding the rigid structures of logical thinking and operating first than them when allowed to manifest freely. In fact, Russ \& Wallace [31] contend that many cognitive abilities and affective processes important in creativity also occur in pretending to play and that this in childhood affects the development of creativity in adulthood.

Goleman [16] and Segal [32] agree in highlighting in the early nineties that Joseph LeDoux [27] discovered the messages from the senses: sight, touch, smell and hearing; first registered by the brain structure that is more involved in the emotional memory; the brain amygdala, long before moving on to the neocortex, where the reasoning processes occur. According to them, this makes the emotional mind much faster than the rational one and goes into action without pausing for a moment to think about what it is doing [23]. Thus, playing manages the emergence of new ideas spontaneously that, in the light of the tradition of the academy, could be irrational, but that in the end eliminates fears and imperfections and develop creativity.

Fink [15] talks about playing as a rejuvenating and renewing power. We know about it because there is something there that reemerges from our earliest joy, and permeates the sphere of maturity to make us feel excitement and euphoria once again. In this context, the presence of an immaterial element of magic that causes men to redeem themselves can be felt. During play, we entertain fantasies, break down preconceived notions, and become more socially and physically flexible. This enables us to navigate unfamiliar territory with greater finesse and ease [6]. In playing, age is not an obstacle to a generational encounter; a grandfather is a child again when he teaches his grandson to play, both operating from timeless principles limited to the epoch they both agreed on and learned from each other to respect the rules and processes of the game. With these lessons, the child will later learn the essential values for life and will begin to create the conditions for living next to others with a sound sense of respect and tolerance.

The essence of playing lies in its capacity to direct the mind towards the achievement of a specific objective while allowing one to be free by getting rid of one's chains and negative thoughts. As Brown and Eberle claim [6] "A play 
state entails and evokes a feeling of being wholly engaged, fulfilled, and delighted. These are states that we don't need to prepare for or reflect back upon. They are states where play functions as a catalyst for our authentic, creative and blissful selves to shine through, whether we are aware of it or not".

Huizinga [19] also states that "by knowing the game, the spirit is recognized" perhaps because playing transcends the spheres of rationality, and allows you to see the nakedness of the soul. The soul evolves within each body and 'reveals itself' to reasoning, but not to the dynamics of playing: the soul knows about the game of love, which is the game of all creatures, and of innocence, which emerges when bodies are left aside to operate. Through playing we show ourselves as we are, we show our fragility or tenacity, our honesty or our tricks.

Fink, in turn, [15] reaffirms the community character of playing: "the individual is not enclosed and cloistered in his individuality, but when playing, we are aware of the collective contact with others with a special intensity" (p.7). Playing promotes freedom by escaping from the confinement of the classroom in the imaginary spaces that it recreates, but also builds it, precisely around the community rules. Rules in school, paradoxically, prohibit playing in class. In fact, most failures to school discipline occur when students play. They do it to show that they are more astute than their teachers, for example. However, this game only makes sense before the others, before the ones who are looking. The norm has evidently been broken when playing, since every game... has a community horizon [15] that validates it and with which you learn to live in community. In fact, "the living being obeys, when playing, to a congenital impulse of imitation" [19] that leads him to repeat what others do, to participate and share the feeling of complicity in the game and, in return, its result that can be either fun or learning.

It is a reality that "we learn very easily what gives us pleasure and enjoyment, using ludic learning tools, hopefully accompanied by the love, affection and understanding needed by the human being" [20]. Still, the 'rigor' of rationality would have us believe that what is really serious and important cannot be taught by playing, but what is more sensible and transcendental to be taught than values, love and tolerance, and everything else that bases humans on the essential principles to live peacefully next to each other. "In that sense, education should be interpreted as a process of cooperation and solidarity, especially in developing compassionate and altruistic attitudes" [20] that develop in the student otherness and self-consciousness, in relation to himself and the other, from which we begin to change the paradigm of competitiveness in which the neoliberal model has plunged us. In this respect, education should lead us to a model of collaboration, compassion and responsibility towards other living creatures that inhabit the planet, both humans and animals.

Playing, besides satisfying a need for relaxation and exercising the student for formal activities that life will require later, certainly "serves as an exercise to acquire selfcontrol" [19] which is one of the most difficult competences or stages to be achieved during childhood and adolescence. Playing contributes stealthily to this, helping to forge selfcontrol in the student. It is undeniable that consciousness of oneself represents a fundamental aspect of our lives, since it allows a level of discernment that enables to identify one's emotions and those of others in a specific context that, in turn, helps us differentiate what really matters. According to Smith [34]: Self-awareness is a process which starts from childhood, and means 'realizing' who I am, the way I am and what my environment is like. It is the ability to know my shortcomings, my abilities, my values, my hopes, my emotions, my thoughts, my attitudes. The ability to have selfawareness allows self-acceptance. At the same time, it makes the individual aware of what he should do, of his responsibilities, and, also aware of the ability to create. It enforces rules of conduct and of organization of his context. In short, to take care of his own life.

This way, playing allows the increase of knowledge of oneself when performing the roles of hero or villain, since the individual leaves himself to interpret them and, upon return recognizes and learns to differentiate himself as a unique and particular entity. Intrapersonal communication facilitates paths for us to wander our near and far intimate fields so that introspection provides images of the emotional world we inhabit. It gives us the ability to realize and accept ourselves and, based on that knowledge, the ability to act accordingly, allowing us to organize and manage personal life [34]. Therefore, by promoting self-awareness, playing helps "knowing one's internal states, preferences, resources and intuitions and use these preferences for decision making, taking a realistic view of our abilities, skills, strengths and weaknesses" [17]. This self-knowledge is related to the selfregulation Goleman [17] defined as the ability to handle internal states, impulses and resources, thus achieving selfcontrol, which becomes the core competence in reaching maturity and in learning processes.

On the other hand, playing promotes creativity as beyond rational thinking; emotional intelligence is put forward as a valid reason to 'think' and let one's imagination fly.

"The mere fact that the evolutionary processes of human beings developed the intellectual brain areas and areas linked to pleasure, over others linked to aggression and depression, helps us to understand how playful activities enable humans to reorient their lives towards construction activities related to learning, creativity and application of knowledge" [20].

Through playing, the freedom to try new things and the freedom to fail is allowed. If during the learning process the margin of error of a person who ignores how to play is constant, then playing should become his essence because, when doing it, to be wrong is valid and the fear to fail is deleted. Likewise, the unpredictability, spontaneity and uniqueness of playing create the conditions to foster creativity because everyone can freely express their ideas in that relative chaos. "A person feels free when playing and, in that freedom, allows himself and others some permissions, as well as to the unforeseen situations that are the beginning of opening those doors locked from childhood" [35] which start 
closing forever when reaching adulthood, depriving us of one of the most beautiful feelings of childhood when almost everything seemed funny to us. Another important feature of playing is that by its nature, not achieving the goal does not hinder the process. This in general does not seem to bother the players but rather it encourages them to learn to overcome the obstacles. Low frustration tolerance is improved and the participants take risks that in real life would be unthinkable, something that enhances their ability to inventiveness and their desire to persist.

Some U.S. organizations such as the Institute of Play, founded in 2007, have begun implementing didactic strategies that encourage learning through playing so as to contribute to changing the structure of education in the United States. The Institute has the mission of promoting the design of games in the classroom to cover the entire curriculum of high school students, so that professional designers make some of the games at the same time others are created by the students in each classroom and subject. Games, especially video and online, can be considered a calamity for social interaction by some, but if used correctly and in academic contexts, it may mean greater permanence or engagement of students in their educational process. At the Institute, the lessons become missions, plans to develop outside the Earth and other planets, for example, including the usual rigors of academic content in projects and the design of materials to be required under adverse planetary conditions. This leads the student to perform beyond normal contexts, to practice other interactions, and to perform other roles.

\section{Playing and Positive Psychology}

It cannot be denied that playing is closely linked with fun and joy. It has been assumed that the university should be a boring place where, cloistered and afraid, young people learn to regulate themselves and to behave towards a society that considers seriousness as a determinant factor for 'success' in life. Seriousness may be necessary, it is true, yet this does not mean that a class has to be boring; a tedious class does not necessarily generate more learning. The spheres of understanding, linked to the proliferation of neural connections that are created in the brain when there is the expectation and possibility of fun, are infinitely superior to those that occur when the fear of making mistakes create a mental block.

Positive psychology and human strengths [4] have gained momentum worldwide and with extraordinary possibilities of renewing educational practice from a sound scientific basis. It has committed itself to examining these other areas of behavior that traditional psychology had sent to exile by focusing more on the pathology of repair than on investigating the negative aspects of wellness and health. New research studies on the self-healing potential of human beings came up in the middle of the last decade of the twentieth century by authors such as $[4,5,33]$. These authors relate its development to affection, optimism and positive aspects of human functioning that enable people to enhance their overall growth, through the care that must be provided to themselves and others. In accordance with Cabrales [8]: the teacher must develop skills to increase the knowledge of his human condition, the care that must be given to himself and his students, for which it is important that he becomes aware of himself, his physical and spiritual particularity, inasmuch as this requires and involves taking ontological knowledge of the individual being (sameness of the person), the others (otherness) and the reality that contains it.

One of the principles of positive psychology is to lay the foundations of a science of happiness. Therefore, its contributions may promote the essential objective of every educator: to empower young people to deploy the most positive aspects - their personal strengths- and enhance their present and future welfare [3]. We have considered the university as a stage. As another link in the goal of achieving happiness which supposedly will come during adulthood when, with a job, we will be able to buy the things we want. However, as mentioned before, the constant change and the uncertainty about the future has made our students more short-term oriented, maybe less transcendent, and more aware of the present in the longing to be happy.

We, as teachers, too often tend to fall into the same mistake: we believe that the welfare of our students will occur in the future, and conceive learning as an endowment of knowledge, skills and attitudes that will bear fruit someday, and will allow them to find a job and create living conditions so that finally, some distant day... they can be happy. We also believe that "being happy" is something that will be given automatically by the mere fact of having a basic education, a job and a family. However, do we really help our students learn to be happy? [3].

From this perspective, and considering that the new postconflict students, and the regular students spend much of their time in educational institutions, it is necessary to promote a pedagogy of happiness and tranquility, a kind that manages less competition and more collaboration, more inclusion, affection and optimism. A pedagogy that includes playing as a teaching strategy so learning is made fun and our youth find in school or university a peaceful place. One that promotes their growth as human beings by sharing a planet with other creatures in which all have equal rights.

\section{Conclusions}

We must implement playing as an effective and premeditated teaching strategy to manage creativity to guide the new post-conflict students, and students of this globalized world, who believe that fun only comes from gadgets and electronic games. By playing, it is possible to remove students from the classroom enclosure with a model in which personal interaction and teamwork prevail. In consequence, when solidarity and mutual understanding are incorporated, educational and cultural values can be represented.

Playing, besides promoting emotional intelligence, otherness, concern for others, and caring for the planet, 
promotes the development of motor skills. It can be a supporting tool in the different areas of the teaching and learning processes, focusing on the emotional, social and intellectual development of students.

Accordingly, universities should promote the development of the emotional intelligence, to incorporate in a peaceful and fruitful way all individuals who will leave the battlefields, support networks for urban militias and other types of criminal organizations. Goleman's emotional intelligence allows for the free development of creativity and the implementation of pedagogical strategies supported in playing. They can be considered valid didactic tools to improve both the cognitive processes and the learning problems of ex-combatants.

We must stop valuing young people for what they will be tomorrow and learn to accept them as the immature beings they are today. We must value them for what they are and do represent today. There is plenty of time for being adults but little for being children. By considering childhood in an analog world as a period when playing was leaving home, sharing with friends until sunset with no cellphones or being looked after by adults, we might have happier children, less stressed out and freer youngsters ready to take the leadership of the chaotic world that they will inherit.

\section{References}

[1] ACEMOGLU, D. Los Orígenes Coloniales del Desarrollo Comparativo: Una investigación empírica. Revista de Economía Institucional, 7(13), 1-51. 2005.

[2] AINSCOW, M. La mejora de la escuela inclusiva. Cuadernos de Pedagogía, Barcelona: n. 349, p. 78-88, sep. 2005.

[3] ARGUÍS, R.; BOLSAS, A.; HERNÁNDEZ, S.; SALVADOR, M. Programa: AULAS FELICES, Psicología Positiva aplicada a la Educación, Equipo SATI, Zaragoza. 2012. Available at: https://www.educacion.navarra.es/documents/27590/203401/ Aulas+felices+documentación.pdf/3980650d-c24-48f8-89fc095acd1 faalb. Consulted on: 19 abr. 2016.

[4] ASPINWALL L.; STAUDINGER, U. A Psychology of Human Strengths: Fundamental Questions and Future Directions for a Positive Psychology. American Psychological Association. Washington D. C., 2013.

[5] BALTES, P.; FREUND, A. Human Strengths as the Orchestration of Wisdom and Selective Optimization With Compensation. In: Psychology of Human Strengths: Fundamental Questions and Future Directions for a Positive Psychology, (Ed): Aspinwall, L., y Staudinger, U., American Psychological Association. Washington D. C., 2013.

[6] BROWN S.; EBERLE M.; A Closer Look at Play. In: Play and Creativity in Psychotherapy, (Ed): Marks-Tarlow, T., Solomon, M., Siegel, D. Norton Professional Book. New York. 2017.

[7] BRUNER, J. Beyond the information given: Studies in the psychology of knowing. New York: Norton, 1973.

[8] CABRALES, O.; OSORIO, S. La condición humana del docente bajo los avatares del Neoliberalismo. In: La Bioética a la Luz de las Epistemologías de Segundo Orden, Editorial UMNG, Bogotá. 2014.

[9] DE BONO, E. New Think. New York: Avon Books, 1985.

[10] EL TIEMPO. ¿Es diferente el cerebro de los jóvenes de la generación Z? Available at: http://www.eltiempo.com/estilode-vida/ciencia/adiccion-a-internet-la-generacion-z-tiene-elcerebro-hiperconectado-/15240317. 2015.

[11] ERIKSON, E. H. Identity: Youth and crisis. New York: Norton. 1968.

[12] ESTEVE, J.; FRANCO, S.; VERA, J. Los profesores ante el cambio social. Anthropos, Madrid, 1977.

[13] DAMASIO, A. El error de Descartes, Madrid: Crítica, 2006.

[14] ESQUIVIAS, M. T. Creatividad: definiciones, antecedentes y aportaciones. Revista Digital Universitaria, Instituto Tecnológico y de Estudios Superiores de Monterrey. 5(1), p. 4-7, january 2004. Taken from:

http://webcache.googleusercontent.com/search?q=cache:http:/ /www.itescam.edu.mx/principal/sylabus/fpdb/recursos/r10256 6. Consulted on: 24 may. 2017.

[15] FINK. E. Oasis de la felicidad, México. Centro de Estudios Filosóficos. UNAM, 1966.

[16] GOLEMAN, D. La práctica de la inteligencia emocional, Kairós, Barcelona, 1998

[17] GOLEMAN, D. Working With Emotional Intelligence. Bantam Books. New York. 2010.

[18] HARGREAVES, A. Profesorado, cultura y postmodernidad. Madrid: Morata. 2003.

[19] HUIZINGA, J. Homo ludens, Alianza, Buenos Aires. 1995.

[20] JIMENEZ, A. El juego nuevas miradas desde la neuropedagogía, Ed. Magisterio. Bogotá. 2008.

[21] MAY, P. Play and creativity, In: The New Early Years Professional: Dilemmas and Debates (Ed) Angela Nurse. Taken from: https://books.google.es/books?hl=es\&lr=\&id=nXOAgAAQBAJ\&oi $=$ fnd $\&$ pg $=$ PA95\&dq $=$ play + and + creativity $\&$ ots $=$ Up8pXSQKWR\&sig $=92 \mathrm{cwAhbacNVzS19XeInm \_ A16F6}$ $8 \# \mathrm{v}=$ onepage $\& \mathrm{q}=$ play $\% 22 \mathrm{nd} \% 20$ creativity $\& \mathrm{f}=$ false. Consulted on: 20 nov. 2017.

[22] NORTH, D. Instituciones, cambio institucional y desempeño económico. México: Fondo De Cultura Económica USA. 1995.

[23] NUÑEZ, M.; SALÓN, J.; ROMERO, G.; ROSALES, V. Inteligencia emocional e intuición como plataforma en el manejo del conflicto y negociación. Available at: Revista Multiciencias, Vol. 9, Núm. 3, septiembre-diciembre, 2009, pp. 259-266, Universidad del Zulia, Venezuela. Consulted on: 24 sep. 2016.

[24] JOHNSON, J. Play and Creativity. Early Childhood Education, The Pennsylvania State University. Available at: test.scripts.psu.edu/users/j/e/.../Play\%22nd\%20Creativity[1].d oc. 2007. Consulted on: 2 may. 2015.

[25] JOHNSON, J.; CHRISTIE, J.; WARDLE, F. Play, development and early education. Boston: Allyn Bacon. 2005. 
[26] LARA, A. Desarrollo de habilidades de pensamiento y creatividad como potenciadores de aprendizaje. Revista UNIMAR, n. 59, Enero-junio de 2012. ISSN 0120-4327.

[27] LEDOUX, J. E. The Emotional Brain. New York: Simon \& Schuster. Foreign Publications of the book. 1996.

[28] PIAGET, J. Piaget's theory, in: PH Mussen (comp), Carmichael's Manual of Child Psychology, vol. 1, p. 703-732. New York, Wiley. 1970.

[29] PONCE, M. La inteligencia, la creatividad y teorías sobre la sabiduría, Revista del Centro de Investigación. Universidad La Salle, vol. 5, n. 19, julio-diciembre, 2002, p. 63-68. Distrito Federal, México.

[30] PRENSKY, M. Nativos digitales, Inmigrantes digitales. On the Horizon (MCB University Press, Vol. 9. 2001.

[31] RUSS, S.; WALLACE, C. Pretend Play and Creative Processes. American Journal of Play, v. 6, n. 1 (c) The Strong. 2013. Available at: http://www.journalofplay.org/sites/www.journalofplay.org/file s/pdf-articles/6-1-article-pretend-play.pdf. Consulted on: 2 apr. 2014.

[32] SEGAL, J. Su inteligencia emocional, aprenda a incrementarla y a usarla, Grijalbo, Barcelona. 1997.

[33] SELIGMAN, M. Learned Optimism: How to Change your mind and your life, Waterbrook Press, London. 2006.

[34] SMITH, C. Pedagogía de lo Humano. La Magia de la educación, Chile, 2007.

[35] TRIGO, E. Creatividad y Motricidad, Norma, Bogotá. 1999.

[36] VERA-VILlarROEL, P.; GUERRERO, A. Diferencias en habilidades de resolución de problemas sociales en sujetos optimistas y pesimistas. Universitas Psychologica, v. 2, p. 2126. 2003.

[37] VIVAS, M.; GALLEGO, D. La Inteligencia emocional, por qué y cómo desarrollarla, Universidad de los Andes, Mérida, Venezuela. 2008. 